POLITEIA: Jurnal Ilmu Politik
Politeia: Jurnal Ilmu Politik, 11 (1) (2019): 10-20
ISSN 0216-9290 (Print), ISSN 2549-175X (Online)
Available online https://jurnal.usu.ac.id/index.php/politeia

\title{
Implementation of Peraturan No. 1 Tahun 2015 on Management and Public Information Service in Binjai General KPU
}

\author{
Fatimah Hanim* \& Evi Yunita Kurniaty \\ Program Magister Administrasi Publik Universitas Medan Area
}

Accepted December 2018, Approved December 2018, Published January 2019

\begin{abstract}
Abstrak
Permasalahan yang diangkat dalam penelitian ini adalah : (1) Kurangnya sumber daya manusia untuk mengisi struktur sehingga terjadinya merangkap jabatan dalam sistem kerja dalam KPU Kota Binjai , (2) Kurangnya sarana dan prasarana di KPU Kota Binjai, (3) Masih kurangnya sosialisasi dalam Implementasi Peraturan Komisi Pemilihan Umum Nomor 1 tahun 2015 . Penelitian ini menggunakan metode penelitian kualitatif, dimana digunakan dalam suatu penelitian untuk memperoleh gambaran secara kualitatif dan akan banyak didominasi oleh kata-kata, kalimat maupun uraian serta jarang menggunakan data-data angka, meskipun tidak menutup kemungkinan ditampilkannya tabel atau grafik untuk mendukung kelengkapan data.Dari hasil penelitian diketahui bahwa dengan adanya Peraturan Komisi Pemilihan Umum Nomor 1 tahun 2015 memberikan dampak yang signifikan terhadap perbaikan dalam pelayanan publik yaitu pelayanan yang semakin baik dalam "satu pintu" oleh PPID, keterbukaan pada akses informasi publik, meningkatnya peran aktif masyarakat, persamaan perlakuan, ketepatan waktu, kemudahan dan keterjangkauan. Walaupun masih banyak yang harus diperbaiki dalam mengimplementasikan Peraturan KPU Nomor 1 tahun 2015 tersebut.
\end{abstract}

Kata Kunci: Komisi Pemilihan Umum, Pelayanan Publik, Implementasi.

\section{Abstract}

The problems raised in this study are: (1) Lack of human resources to fill the structure so that concurrent positions occur in the work system in Binjai City KPU, (2) Lack of facilities and infrastructure in Binjai City KPU, (3) Still lack of socialization in Implementation Election Commission Regulation Number 1 of 2015. This study uses qualitative research methods, which are used in a study to obtain a qualitative description and will be dominated by many words, sentences and descriptions and rarely use numerical data, although it does not rule out the possibility of displaying tables or graphs to support the completeness of the data. From the results of the study, it is known that the existence of Regulation of the General Election Commission No. 1 of 2015 has a significant impact on improvements in public services, namely services that are getting better in "one door" by PPID, openness to access to public information, increasing active role of society, equality of treatment, timeliness, ease and affordability. Although there is still much to be improved in implementing the 2015 KPU Regulation No. 1.

Keywords: General Election Commission, Public Service, Implementation.

How to cite: Hanim, F. \& Kurniaty, E.Y. (2018), Implementasi Peraturan Nomor 1 Tahun 2015 tentang Pengelolaan dan Pelayanan Informasi Publik di Lingkungan Komisi Pemilihan Umum Kota Binjai, Politeia: Jurnal Ilmu Politik, Vol 11, (1): 10-20

\footnotetext{
*Corresponding author:

E-mail: vie_holmes@rocketmail.com
} 


\section{INTRODUCTION}

The existence of public participation is very important in electoral process, therefore information disclosure needed to encourage public participation. Information disclosure requires transparency regarding election holding in the society, particularly any information related to the implementation of the general election aims to create a reciprocal trust between election commission and community through the provision of information and ensure the convenience in obtaining information. Information transparency is needed so public supervision against electoral process can be carried out objectively. For this reason, it is necessary to provide data through an infomation and documentation system that can be easily accessed. Those data include legislation formulation and content pattern, regulations and public policies and implementation by each state institution.

\section{Open Government (open} government) is the foundations of accountability aspect in democracy. In a Government that is open, public information disclosure is a must because only by its presence the Government can run transparently and public participation occurs optimally in all management process. The management process includes all resources process, starting from decision-making, implementation, and the evaluation as well. In order to support this complex process, a declaration should be built to participate in this collective life.

Public information disclosure is one of good governance indicators. Indonesia itself has been guaranteeing the citizen's right to communicate and obtain information in accordance with Article
28F 1945 CONSTITUTION, which reads: "everyone has a right to communicate and obtain information to develop personal and social environment, as well as the right to seek, acquire, possess, store, process, and deliver the information by using any kind of available channels ".

Then the presence of Act No. $14 / 2008$ on the openness of public information demonstrating the Government's commitment to embody good governance based on the transparency principle .. Thus, the discourse about transparency or disclosure on the conduct of the State is no longer a concept, but already a practice that possess strength of law and government must disclose all information on how they conduct the state to the public and the public has the right to obtain those iinformation.

In this study the authors are interested in seeing the openness of public information on KPU (general elections commission) through the implementation of Peraturan No. 1 Tahun 2015 (Regulation no.1/2015) on the information management and service in KPU environment. Because information disclosure is a situation where information available and can be given and obtained by community. Information disclosure is a condition that allows community participate in organizing an elections. It is expected that public disclosure could increase public participation in elections process in Indonesia.

KPU, as one of the country's institutions are carrying out the mandate as agency to conduct the election, has a role in supporting public interest so that information disclosure become a supporting factors in realizing the public 
accountability and public supervision. It also optimize Peraturan No. 15 Tahun 2011 on conduction of election based on the reasonable, openness, professionalism, and accountability principle.

The spirit of KPU in supporting of public information disclosure has been seen since 2010, when KPU started to conducting KPU regulation intensively (peraturan KPU or PKPU) to standarize the information management and service, whether in the Provincial KPU, RI/KIP Aceh, and KPU/KIP Kabupaten/Kota. Later in March 2015 KPU confirms PKPU No.1 of 2015 about management and Public information service on KPU.

It needs to be explained that the validation of Peraturan no. 1 tahun 2015 (effective on 27 March 2015) has turn it into law, thus become the reference for any KPU in Provinces and city on managing public information services in every unit. KPU also create additional regulation under Surat Keputusan KPU No. 87/Kpts/KPU/of 2015 about information management and documentation service officers structure in KPU and Surat Keputusan KPU No. 88/Kpts/KPU/of 2015 about Standard Operational Procedures on information management and service in KPU.

With the publication Peraturan no. 1 tahun 2015 on management and public information service, KPU formed officers who manages the information and documentation electoral comission or Pusat Pelayanan Informasi Publik Komisi Pemilihan Umum (PPID KPU). PPID KPU is the evidence of the tranparency principle of the elections process or Pemilihan Umum (PEMILU) to the public. PPID KPU become a form of transparency itself.. Whether it is transparent on stages, transparent on budgeting and also transparent on lists of voters and the results of the recapitulation in the polling stations or TPS

.Before Peraturan no. 1 tahun 2015 validated and the PPID has not been created, community complained about the difficulty on how to obtain or seek information from Binjai KPU related to the elections, whether presidential elections, governor, mayor or senator. The reason is because KPU gave a very limited access to public information and the information are highly selective. This is because the absence of special work unit to serve people who want to get access to the information regarding the performance of KPU and the holding of elections.

However, after the establishment of Information and documentation Management Officer (PPID), the exist problems such as providing information can be addressed by the KPU bit by bit. Particularly for Binjai KPU there are still constraints occurs. It happens when an officers who already have an structural position at KPU got selected as an officer PPID. This creates overlapping task or doubles job position at Binjai KPU office.

Applicants who want to get information from KPU generally are students, NGOs, political parties, and common people who conduct a research or doing monitoring function. Binjai KPU officers could have responded more quickly if the offcials PPID focused and be professional in one job only.

The lack of human resources existing in the Binjai affects the process of giving 
information online. The information provided from Binjai rated low because the news or information not directly distributed to the public through e-PPID website.. It happens because the task of managing PPID website ran by officers who also have responsibility on another task. The lack of human resources at Binjai KPU made the officers had to perform tasks in several fields of work.

In this study the author chose Binjai KPU as the research object, because Binjai $\mathrm{KPU}$ is one of the chosen office to conduct electoral socialization for beginner voters, and the task are run entirely by the information and documentation Officer (Binjai PPID KPU). This research is trying to build a framework on understanding what kind of efforts Binjai KPU do to increase public access to information in the region and what challenges Binjai KPU must face in an attempt to improve the public access to information in KPU.

Based on the description, the authors feel interested in conducting research on: "the implementation of KPU Peraturan no. 1 tahun 2015 about the management and service of public information on the environment in KPU; The openness of public information in of Binjai KPU."

\section{RESEARCH METHODOLOGY}

This article using qualitative research methods that are theoretically different from quantitative research. The difference lies in the difficulty in making research design, because qualitative research generally don' have pattern.

Qualitative research is an research using approach called investigation because researchers typically collect data directly, face to face and interact with people on location where the research took place (McMillan \& Schumacher, 2003).

Furthermore, qualitative research according to Moleong (2007:6) is a research intends to understand a phenomenon that is experienced by research subject, for example behaviors, perceptions, motivations, actions, etc.., holistically, and then descripting it using words, in a specific natural context and by utilizing a variety of natural methods.

This research emphasize on the disclosure of the meaning of implementation of KPU regulation named Peraturan No. 1 Tahun 2015 about management and service of public information on the environment of KPU, as well as the obstacles that appear in it.

\section{RESULTS AND DISCUSSION}

Implementation of rule Peraturan No. 1 Tahun 2015 on management and Public information service at Binjai KPU.

Implementation of Peraturan No. 1 Tahun 2015 with the establishment of Information and documentation Management Officer (PPID). In this study the authors will focus on discussing Peraturan No. 1 Tahun 2015 on management and public information service at Binjai KPU. Public service reformation is the prime mover which considered as a strategic step to renewal the practice of governance (Dwiyanto, 2005).

The quality of service is determined by many factors which are intangible and have complicated psychological aspects to be measured (Zaithaml, Berry and Parasuraman,1990). 
Ideally, the measurement of quality service carried out against two interrelated dimensions, that is assessment of customer satisfaction on users/customers and assessment on service providers (Hendrikus Triwibawanto Gedeona, Journal Of The Science Of Administration).

Implementation of Peraturan No. 1 Tahun 2015 at Binjai KPU:

\section{Information Services from "1 door"}

Implementation of the regulation is embody by opening public information services provided by KPU. Merilee s. Grindle's theory, known as "Implementation as A Political and Administrative Process" of public policy implementation. The second variable is set to seeing if the policy achieved its purpose on affect society as individuals and groups. The community felt there was a improvement on the direction of public services provided by KPU through the PPID. Ahmad Azis Azra'i, MM, member of Gerindra Party said:

"There are many improvement here on public information service. In the past there was no obvious position at Binjai KPU office that provides the information needed by our party. But now I can ask directly to Binjai PPID officers. I. can say the service here is 1 door information provide service.

2. The services standard has been following the KPU's public information service standard as said by Laili Hafni (public), a student who wanted to retrieve data for her college final paper. She said:

"The service provided by the KPU is really good. I immediately directed by
KPU officers to PPID. And my requests for retrieving data immediately responded by friendly PPID officers".

About the procedure of the public information service at Binjai KPU are described by Mr. Fernando s. M Pinem, s. Sos (one of the information and documentation provide service officer at Binjai KPU). He said:

"For procedure of the public information service, people can come to service desk and filling out the request form. After the request made to the person in charge (PPID officers), then the PPID officers will order another officers to prepare everything necessary related to the information that required. The desk will be informed about the further process. PPID officers contacted the applicant and explain how long it took to prepare the complete data/information that has been required. After the data given to applicant, the officer's desk must report back to the officers of the PPID.

The nature of public service are (Erick s. Holle, Journal of Sasi):

a. improving the quality and productivity of the duties and function's execution of the Government in public service.

b. Encourage the efforts to increase the effectiveness of service system and governance in order to create more effective and efficient public service.

c. Encourage the growth of creativity.

The implementation of information services already filled by Binjai PPID KPU in 2016-2017 are: 
1. The amount of the information applicant in 2016 is: 50 Applicants

2. The amount of the information applicant in 2017 is: 18 the applicants

Total Information applicant: 68 the applicants

3. Public service by Binjai PPID following the command letter issued by the Central KPU.

Policy implementation by Grindle theory, the success of the implementation of the policy determined by its process, by questioning whether the implementation of policies in accordance with the action of policies and in accordance with its design. Providing public information, PPID officers always following the command letter issued by the Central KPU on information service announcement. It is described by $\mathrm{Mr}$. Fernando S M Pinem:

"We're on the job to provide public information always following the command letter No: 44/the/I/2015, dated 26 January 2015, on information service announcement at KPU/KIP. Which is the continuation of rule No. 1 of 2015 about the management and service of public information ".

It is also said by the PPID officers desk service. After the applicant i.e. the community come to the service desk. Then the mechanism of public information service established by the KPU, as spoken by Mother Gloria Dwi Febrin Tampubolon PPID officers KPU city of Binjai, she said:

"The mechanism we run in accordance with the instructions of PPID officers following command letter No.
44/the/I/2015, dated 26 January 2015 on Information service announcement at $\mathrm{KPU} / \mathrm{KIP}$, that is the applicant coming to service desk, fill out the information request form and attaching a photo copy of applicant and user of the public information. The officer provides public information Acceptance Request form to the applicant. Then the officer processing the applicant's request following the request form which has been signed by the applicant. We give the information only as requested. If the requested information is entered in the category of excluded, PPID will explain the reason according to regulation. Then our officers will provide submission public information notice form to the users of public information ".

4. Public information disclosure and Binjai PPID's professionalism.

The success of a public policy implementation according to Grindle largely determined by the level of implementability policy itself, i.e. the content of the policy which is consist of:

\section{a. Interest Affected}

In a Government that is open, public information disclosure is one of necessity due to the presence of the openness of public information, the Government can run transparently and public participation occurs optimally in all Government's management process. The presence of Act No. 14 of 2008 about the openness of public information demonstrate the Government's commitment to embodying the good governance which is based on transparency principle. And for that the Government requires the State institutions to do a public service that is open to the public. Following that order, 
KPU made the Peraturan No. 1 Tahun 2015 on the management and service of public information in KPU.

Beside following the regulation, information disclosure is also demanded by public. The meaning of public here include political parties, interest groups, NGOs, academics and others. The Government should openly provide information to the public.

The presence of good information disclosure could help the public doing their job to supervise the election process and to prevent all mal-administration actions or even prevent an election criminal's act.

The presence of information disclosure is one of the main indicators of the election's holding that based on trustworthiness and democratic, and also as an act of human rights, named the right to know.

\section{b. Type of Benefits}

The purpose of the public information service is:

1. Guarantying the Indonesia's people right to access public information on KPU, including the Provincial KPU/KIP Aceh and Provincial/City KPU/KIP.

2. Encouraging public participation in the process of taking policy on KPU, including the Provincial KPU/KIP Aceh and Provincial/City KPU/KIP 3. Promoting the active role of the of managing information request and community, particularly to participate in Elections process
4. Improving the Election's holding process by KPU, including the Provincial KPU/KIP Aceh and Provincial/City KPU/KIP based on transparent, effective, efficient, and accountable principle.

5. Improving the quality of information management and service on KPU, including the Provincial KPU/KIP Aceh and Provincial/City KPU/KIP.

6. Guarantying public information service on KPU, including the Provincial KPU/KIP Aceh and Provincial/City KPU/KIP.

\section{c. Extents of Change Envision}

The extents of change to achieve in public information disclosure on KPU is to see the implementation of public information governance from institution's aspect and the availability of information as an indicator of the degree of change that would like to achieved.

From institution's aspect, the compliance of the Binjai KPU can be measured by this following indicators:

(1) Binjai KPU has formed and sets the PPID

(2)Binjai PPID have standard operational procedure of public information service

(3) Providing PPID/public information service menu in the page official website of KPU i.e. kpud-binjaikota.go.id

(4)Binjai PPID conveying the mechanism objections as a part of public's right to know the objection's reason of an information and submission request. 


\section{d. The Site of Decision Making}

The site of decision making on public service in delivers, publishes and announces public information on Binjai KPU following the directive order from North Sumatra KPU (Provincial KPU) and bound to Central KPU directive order.

\section{e. Program Implementer}

Composition of the member of the Information and documentation Management Officer (PPID) Binjai KPU consist of: PPID's elder committee: Herry Dani, SE, MAB, Tim Pertimbangan Drs. H. Labayk Simanjorang, MA Chaisal Andrio, S.Pd dan Rafli Subakti, SHZulfan Effendi, ST Atasan PPID Sugianto, BATim Penghubung Fauziah, SE dan David Aulia, A.Md Desk Pelayanan Yusilawati, SH dan Febrin D. G. Tampubolon, S.Sos, sh. and d. g. Febrin Tampubolon, s. Sos

\section{f. Resources Committed}

Binjai PPID on carrying out the mission to provide public information services to the applicant/user assisted by first officers from these position: achieve, librarian, public relations, and computer. The officer on the service desk must know all the regulations related to the openness of public information and public services, and have the communication's skills and attitude in order to carrying out the tasks of public information service.

Based on article 4 of the ACT on the public service, the implementation peraturan KPU No. 1 tahun 2015 is using basic public services principles, which are:

a. That the granting of public services at Binjai KPU put priority to no personal interests nor groups. It is proven that anyone who wants to get public information served properly. All applicant served by the same rule in accordance with the SOP.

b. The existence of legal certainty in providing public service based on command letter issued by KPU. In addition there are still some rules that could use as reference to standardize the public services.

c. The equality in providing services that did not discriminate people based on their tribe, race, religion, class and economic status.

d. The fulfillment between right and obligations must be carried out either by KPU officers and people who want to obtain public information.

e. in the term professionalism there are still a few notes to be fixed such as: PPID officers should have competence in accordance with his duties to provision public information service. The existence of overlapping jobs that caused PPID officers responsible to another structural task at Binjai KPU. In addition to that, training or socialization should be given towards the implementation of Peraturan No. 1 Tahun 2015.

f. The public's role is increasing in accordance with openness of public information services after Peraturan No. 1 Tahun 2015 implemented.

g.PPID officers give equal treatment in delivering public services.

h.Public can easily access and obtain information about the desired service. 
i.Organization of the public service given by officers of the PPID has been following the regulation.

j. KPU Binjai committed in providing facilities and special treatment for vulnerable groups.. But until now there has never been difabel that comes directly to the city of Binjai to request information.

k. every type of service completed on time in accordance with service standard.

1. speed, ease, and affordability of any service performed in a quick, easy and affordable.

The Constraints in the implementation of the General KPU Peraturan no. 1 tahun 2015.

External and internal constraints in the implementation of the public information service is:

1. Peraturan no. 1 tahun 2015 has not socialized optimally in the internal KPU so the spirit to promoting the openness of public information have not been distributed evenly.

As expressed by Mr. Herry Dani, SE, $M A B$, the Chairman of Binjai KPU, that this regulation still considered as a new regulation and there has never been a special training or socialization on understanding this new regulation. The comprehension of public information disclosure has not been distributed evenly among PPID officers at Binjai KPU. The newly appointed PPID officers still need a lot training to be able doing their duty professionally and serve community on accessing public information
After the PPID officers are well-trained and well-socialized, they are expected to be professional at their job, reliable and responsible. Like the theory of Merilee s. Grindle that the success of implementation of the policy, one measured by the level of compliance and responsiveness of the executor. The thing that is considered important in the process of implementing a policy is compliance and the response of the PPID officers at Binjai KPU on doing their duties, respectively and how well the officers complying and giving response to every policy that comes with the new regulation. After peraturan No. 1 tahun 2015 is executed properly, there should be a significant increase in the public information service at Binjai.

2. The limitation of facilities and infrastructure of public information service;

Due to the quite new regulation, PPID officers at Binjai KPU are aware about the lack of infrastructure and facilities on accessing public information. One of the problems that often happen is broken internet connection. It made the process of updating information for the Binjai city is often delay. The computer that is use for updating public information by PPID officers is also use to do another job.

3. Management of the archive has not been arranged well;

Beside the lack of infrastructure and facilities, the lack of human resources also a problem. The KPU employees are doing double job, those are to complement their task as KPU worker unit and became officer of the PPID. In addition there is no 
particular officer in charge for the management of the archives.

Mr. Sugianto, BA, the secretary of Binjai KPU and senior Binjai KPU PPID officers derscribe that there should be an officer with archive management degree to doing this job. The archives on Binjai KPU are well arranged but not good enough.

4. Most of public information are hardcopy

According to people who want to get the information of the public, named Rina Oktora (student), the constraints she have to face to get data from KPU for her final paper is it sill in hardcopy form. She had to copying these files in large quantities. She think it was not practical and expensive.

5. The structure of the PPID officers is already formed, but each function has not been run optimally.

As explained earlier that Binjai KPU is lack of human resources. Although the structure of the PPID already formed and set, but those officers have double job and overlapping task. They serve as an worker unit in structural KPU and also in the PPID. For example Mr. Fernando S M Pinem who served as chief of technical at Binjai KPU also appointed as PPID manager at Binjai KPU.

6. e-ppid Page needs a lot of improvement to facilitate community' access to public information.

It is expected, with the addition of new facilities and infrastructer, e-ppid could facilitate public on accessing information optimally.
Even with the lack of infrastructure and facilities, the PPID officers always put their best on providing information to applicants. The follow-up efforts to improve the quality of information services, including:

1. Socializing the Act, regulations and the decision of KPU RI on implementation of the public information service at internal Binjai KPU, an effort to embody that spirit by visiting high schools in Binjai city to enlighted the new voters about the duties of Binjai KPU's PPID

2. Continue doing improvement on archives management and arrangement by making inventory from all information list in each Sub Division at secretariat Binjai KPU.

3. Identify the types of information that is potentially excluded.

4. Gradually continue to complement the information post into e-Binjai PPID KPU in order to facilitate information access for the public.

E-services have several benefit, mention as follows (Sasi, Journal Vol 17):

a) Increase the efficiency and effectiveness of the Government's service.

b) Speed up the process of granting a service to community

c) The information that provided will be more complete, update, and accurate with less budget in the term of managing data and information retrieval.

d) Support the establishment of good governance 
e) Attract investors and business quality of information management and community to enter government territory. service.

f) Could accelerate the report process Implementation of Peraturan No. 1 Tahun when needed by policy makers.

2015 in PPID of Binjai KPU: PPID officers always refer to command letter of KPU on

g) Improve the interaction with business the announcement of public information. world

In providing public services the significant change that can be seen is at

h) Empower the community by the "one door" service by PPID, the distributing information and transparency as well as decision making process.

i) aviailability of an up to date Provincial/city database openness on public information access, the increasing active role of the community, the equality of treatment, on time service, convenience and affordability.

In the implementation of peraturan No. 1

5. Annually updating the information's list

6. Optimize all functions already formed in PPID's structure at Binjai KPU.

7. Maximize existing infrastructure and facilities to support the public information service.

8. Providing excellent service: with fast service and easy.

\section{CONCLUSION}

The successful of Implementation of Peraturan No. 1 Tahun 2015 can be measured from the achievement process of the final outcome which is the guarantee that every Indonesia's citizen can access public information on KPU, to encourage public participation in policies making process, to increase the active role of the community particularly to participate in elections, to improve the election's holding, based on transparency, effective and efficient, accountable, and responsive principle, to improve the

tahun 2015, the compliance of Binjai KPU to the regulation can be measured from following indicators: the city of Binjai already form and set PPID, Binjai PPID have SOP or standart operational procedures on providing public information, provides PPID/public menu at Binjai KPU's official website (kpudbinjaikota.go.id, and Binjai PPID officers conveying mechanism of managing request and objections as a part of public rights to know how to submit an information request and deliver an objections.

External and internal constraints in the implementation of the public information service are:

1. Peraturan No. 1 Tahun 2015 has not been promoted optimally in the internal environment of KPU so that the spirit of openness of public information on KPU have not been evenly distributed.

2. The lack of facilities and infrastructure of the information service

3. Archive has not been arranged well; 
4.Most public information are hardcopy and it creates difficulty to the applicants

5. Structure of PPID is already formed, but each function has not been run optimally

6. e-ppid Page needs a lot of improvements to facilitate information access to the community.

\section{BIBLIOGRAPHY}

Dwiyanto, A. (2005). Mewujudkan Good Governance melalui Pelayanan Publik, Yogyakarta: Gadjah Mada University Press.

Huda, N. (2005). Hukum Tata negara Indonesia. Jakarta : PT Raja Grafindo Persada.

Nugroho, R. (2006). Kebijakan Publik Untuk Negara-Negara Berkembang, Jakarta: PT. Elex Media Komputindo.

Lukman, S. (2000), Manajemen Kualitas Pelayanan, Jakarta: STIA Lan Press.
Dunn W.N. (2000). Analisis Kebijakan Publik. Yogyakarta; Gadjah Mada University Press

Vallerie, Z.A, Passuraman, A. \& Berry L.L. (1990). Delivering Quality Service: balancing Customer Perception and Expectation, Canada: Maxwell Macmillan.

Bisnis \& Birokrasi, Jurnal Ilmu Administrasi dan Organisasi, Vol. 16, No. 2, MeiAgust 2009, hlm. 87-95

Jurnal Dialog Kebijakan Publik, edisi 3/9/2011

(http:/ / www.setkab.go.id/artikel-4915.html)

Laporan Pelayanan Informasi Publik, ppid.kpu.go.id $/$ ?download $=201604221$ 45414

Jurnal Sasi Vol.17 No.3 Bulan Juli-September 2011

Wikipedia. 2011. Komisi Pemilihan Umum. Diunduh tanggal 16 November 2011 dari http://id.wikipedia.org/wiki/Komisi _Pemilihan_Umum 